\title{
Towards the scale up of a pressurized-jet microfluidic flow-through reactor for cost-effective electro-generation of $\mathrm{H}_{2} \mathrm{O}_{2}$
}

Pérez, José Fernando; Llanos, Javier; Sáez, Cristina*; López, Conrado; Cañizares, Pablo; Rodrigo, Manuel Andrés

Chemical Engineering Department, Facultad de Ciencias y Tecnologías Químicas. University of Castilla-La Mancha, Edificio Enrique Costa Novella. Av. Camilo José Cela $n^{\circ} 12,13071$ Ciudad Real, Spain

*Corresponding author: Cristina.saez@uclm.es

\begin{abstract}
The performance of a novel pressurized-jet microfluidic flow-through electrolyzer for the production of aqueous solution of $\mathrm{H}_{2} \mathrm{O}_{2}$ is assessed in this work. The reactor design is based on three aspects $i$ ) minimizing ohmic drops, by reducing the interelectrode gap to $150 \mu \mathrm{m}$ and the use of a Duocel ${ }^{\circledR}$ aluminum foam as cathodic support; ii) maximizing mass transport, due to the use of three-dimensional electrodes fed in flow-through and iii) optimizing the aeration system coupling a pressurized circuit and a jet aerator. Results show that $\mathrm{H}_{2} \mathrm{O}_{2}$ can be produced with an instantaneous current efficiency of $\cong 100 \%$ up to $20 \mathrm{~mA} \mathrm{~cm}^{-3}$ and a corresponding production rate of $13.1 \mathrm{mg} \mathrm{H}_{2} \mathrm{O}_{2} \mathrm{~h}^{-1} \mathrm{~cm}^{-3}$ in a cathode of $16.5 \mathrm{~cm}^{3}$. Low ohmic resistances were measured even in low-conductive electrolytes, as for example $6 \Omega$ in $0.0035 \mathrm{M} \mathrm{Na}_{2} \mathrm{SO}_{4}\left(0.7 \mathrm{mS} \mathrm{cm}^{-1}\right)$. The electrical energy consumption of $3.65 \mathrm{kWh} \mathrm{kg} \mathrm{H}_{2} \mathrm{O}_{2}{ }^{-1}$ at $10 \mathrm{~mA} \mathrm{~cm}^{-3}$ in $0.05 \mathrm{M} \mathrm{Na}_{2} \mathrm{SO}_{4}$ is the lowest reported so far in neutral-acid medium, confirming the cost-effectiveness of the system. A preliminary scale-up by increasing the cathode volume three times (up to $49.5 \mathrm{~cm}^{3}$ ) allowed the production rate to be multiplied by the same factor and confirms that the system is scalable. Theoretical calculations suggest that the cathode could be expanded up to 3,600 $\mathrm{cm}^{3}$ ( $1 \mathrm{~m}$ thickness) under those aeration conditions ( 6 bar and $160 \mathrm{dm}^{3} \mathrm{~h}^{-1}$ recirculation flow).
\end{abstract}


Keywords: hydrogen peroxide; jet; pressure; microfluidic; flow-through; cell design 


\section{Introduction}

The hydrogen peroxide $\left(\mathrm{H}_{2} \mathrm{O}_{2}\right)$ is a common and widely used compound in many industrial processes and domestic applications (Campos-Martin et al., 2006; Ciriminna et al., 2016; Chen, 2006). Among the different production processes, electrochemical synthesis by oxygen reduction reaction is particularly interesting due to the use of easyto-control and fully electrically-powered systems which allows to obtain $\mathrm{H}_{2} \mathrm{O}_{2}$ in situ and on demand, avoiding the issues related to transport, storage or manipulation of this chemical (Petrucci et al., 2016). As attractive as it may be, at the current level of development the process is not mature enough to compete with current technologies and still work has to be done on this regard.

Design of electrochemical reactors is a complex and multivariable process. A number of aspects ranging from fundamental electrochemistry (electrode material, electrode/electrolyte interphase...) to industrial-scale considerations (flow patterns, mass transport regimes, electrical connections and current distribution, cell geometry and fabrication, costs...) have to be taken into account (De Francesco and Costamagna, 2004; Goodridge and Scott, 1995; Pletcher et al., 2014). In the case of $\mathrm{H}_{2} \mathrm{O}_{2}$ electrolyzers, the most studied variable is the cathode nature (Moraes et al., 2016; Petrucci et al., 2016; Verdaguer-Casadevall et al., 2014). Carbonaceous materials are considered the most adequate option in terms of cost, availability and environmental impact (Zhao et al., 2018). Apart from the nature of the cathode, other variables are involved such as the $\mathrm{pH}$, electrolyte concentration, inter-electrode (IE) gap or the aeration system, to design a costeffective electrolyzer for real implementation in the industry.

Probably the closest-to-market design was a trickled-flow cell with a packed-bed carbon black/PTFE (CB/PTFE) coated graphite chips cathode developed by Dow Chemical/H.D. Tech for the production of $\mathrm{NaOH} / \mathrm{H}_{2} \mathrm{O}_{2}$ mixtures for paper and pulp bleaching (Foller and 
Bombard, 1995; Pletcher and Walsh, 1990). To the best of the knowledge of the authors, its application is restricted so far to one industrial-size $\left(1\right.$ ton day $\left.{ }^{-1}\right)$ plant built in the 80 's in Canada (Gupta and Oloman, 2006; Pletcher and Walsh, 1990). Unfortunately, this design is limited to the production of $\mathrm{H}_{2} \mathrm{O}_{2}$ in concentrated $(\approx 1 \mathrm{M})$ alkaline solutions because cell potential becomes unacceptably large in more diluted $\mathrm{NaOH}$ solutions and also by the relatively low superficial current density and consequent high capital cost working under room pressure (Gupta and Oloman, 2006; Pletcher and Walsh, 1990).

For other uses of $\mathrm{H}_{2} \mathrm{O}_{2}$, such as organic synthesis or wastewater treatment, it had better be produced in neutral-to-acid media containing lower electrolyte concentrations (Pletcher, 1999). Yamanaka et al. reported the use of a membrane electrode assembly (MEA) with a solid polymer electrolyte (Nafion-H) to produce $\mathrm{H}_{2} \mathrm{O}_{2}$ in salt-free solutions (Murayama and Yamanaka, 2011; Yamanaka and Murayama, 2008). This electrode layout is an adequate solution to carry out the production in the absence of a conductive liquid medium but the use of a solid electrolyte increases manufacturing complexity which may result in higher investment costs.

An alternative to the use of a MEA is a narrow IE gap. Scialdone et al. studied the production of $\mathrm{H}_{2} \mathrm{O}_{2}$ for the electroFenton process in microfluidic cells (i.e. with an IE gap in the order of micrometers) to minimize ohmic resistance in the electrolyte and achieve reasonable cell potentials (Sabatino et al., 2016; Scialdone et al., 2013). However, gas evolution together with the low electrolyte flows (in the order of $\mathrm{mL} \mathrm{min}{ }^{-1}$ ) commonly used in those systems may cause an appreciable ohmic potential drop, due to the hold-up of poorly conducting gas bubbles, which discourages the application of high current densities (Bouzek et al., 2010; Křišt'ál et al., 2008; Vogt, 2012).

The reaction rate of electrochemical processes is often mass-transfer controlled given the heterogeneous nature of this type of reactions (Martinez-Huitle et al., 2015). 
Conventional two-dimensional electrodes can be substituted by three-dimensional (3D) electrodes (meshes, foams, packed or fluidized particles) to overcome the mass-transfer bottleneck and achieve higher space-time yields (Heitz and Kreysa, 1986; Walsh et al., 2016; Zhang et al., 2013).

Mass-transfer kinetics are also a function of hydrodynamics within the system. The masstransfer coefficient $\left(\mathrm{k}_{\mathrm{m}}\right)$ is found to be higher when the electrolyte flows through the electrode (Heitz and Kreysa, 1986; Pérez et al., 2018a). Different authors studied the use of $3 \mathrm{D}$ flow-through carbonaceous electrodes to increase $\mathrm{H}_{2} \mathrm{O}_{2}$ production rate, including reticulated vitreous carbon (RVC) (Li et al., 2014), carbon felt (CF) (Gupta and Oloman, 2006; Pérez et al., 2016; Pérez et al., 2017b) and fixed (Chmayssem et al., 2017; Lei et al., 2013) or fluidized beds (Oloman and Watkinson, 1975) of carbon chips.

Another key aspect of $\mathrm{H}_{2} \mathrm{O}_{2}$ electrolysers is the manner in which oxygen is supplied to the electrolyzer, given the low solubility of oxygen in water under room conditions (Scialdone et al., 2015; Tang et al., 2016). The simplest aeration system, bubbling oxygen/air into the solution, suffers from important oxygen transfer limitations. Significantly better results are obtained in terms of production rate and current efficiency (CE) supplying directly the gas to the electrode surface as in gas diffusion electrodes (GDEs), but still present some drawbacks on larger scale applications. For example, low oxygen utilization and difficulties to avoid the excessive gas percolation or electrolyte penetration at gradients of bottom-to-top hydraulic heads equivalent to more than $0.2-0.3$ m (Foller and Bombard, 1995; Gullá and Krasovic, 2014; Pérez et al., 2018b).

Previously, the use of the jet aerator (Pérez et al., 2016; Pérez et al., 2017b), a compressorfree aeration system based on the Venturi effect to aerate $\mathrm{H}_{2} \mathrm{O}_{2}$ electrolyzers was investigated. In addition, the positive effect of pressure on the electrochemical generation of $\mathrm{H}_{2} \mathrm{O}_{2}$ was also studied (Pérez et al., 2017a). In a previous work (Pérez et al., 2018b), 
the synergistic coupling of a pressurized circuit with a jet aerator was demonstrated, giving rise to a powerful aeration system: the pressurized-jet aerator (PJA). This system provides large oxygenation rates at moderated pressures, both to the higher oxygen solubility under pressure and the efficient generation of pressurized air bubbles. As an example, the aeration rate is three times superior (7.6 vs. $21.9 \mathrm{~g} \mathrm{O}_{2} \mathrm{~h}^{-1}$ ) in the system using the PJA compared to the pressurized system without it, both at 6 bar and $160 \mathrm{dm}^{3}$ $\mathrm{h}^{-1}$ recirculation rate of electrolyte.

With this background, an innovative reactor with a state-of-the-art aeration system, an advanced cell layout and three-dimensional electrodes is evaluated in this work to address some issues of current $\mathrm{H}_{2} \mathrm{O}_{2}$ electrolyzers. To do this, a description of the design of the prototype is firstly offered. Within the experimental section, the effect of the current density and electrolyte conductivity on the performance of the reactor is studied and results are compared with the most relevant works in this field. Prompted by the promising results, a first approach towards the scale up of the system is conducted by increasing the cathode thickness to augment the production rate.

\section{Materials and methods}

\subsection{Experimental set-up}

Figure 1.a shows a picture of the experimental set-up. Prior to electrolysis, the tank (left side in Figure 1.a) is filled with the electrolyte solution $\left(2.25 \mathrm{dm}^{3}\right)$ and pressurized up to the desired value. It is important to note that the upper part of the tank must not contain water liquid to allow the air suction from the jet. The electrolyte is recirculated up to 160 $\mathrm{dm}^{3} \mathrm{~h}^{-1}$ by a Micropump ${ }^{\circledR}$ GB - P25 J F5 S A head coupled to a DB 380 A 24 V engine with speed control 0-5V DC supplied by Techma GPM s.l.r. (Milan, Italy). Pipelining, tank, cell (Figure 1.b) and jet (Figure 1.d) were fabricated in plastic materials: polyvinyl 
chloride (PVC) and polyamide $\left(\right.$ Tecalan $\left.^{\circledR}\right)$. A transparent pipe made up of crystal PVC (Figure 1.c) is placed right before the inlet of the electrochemical cell to observe the bubble pattern. 

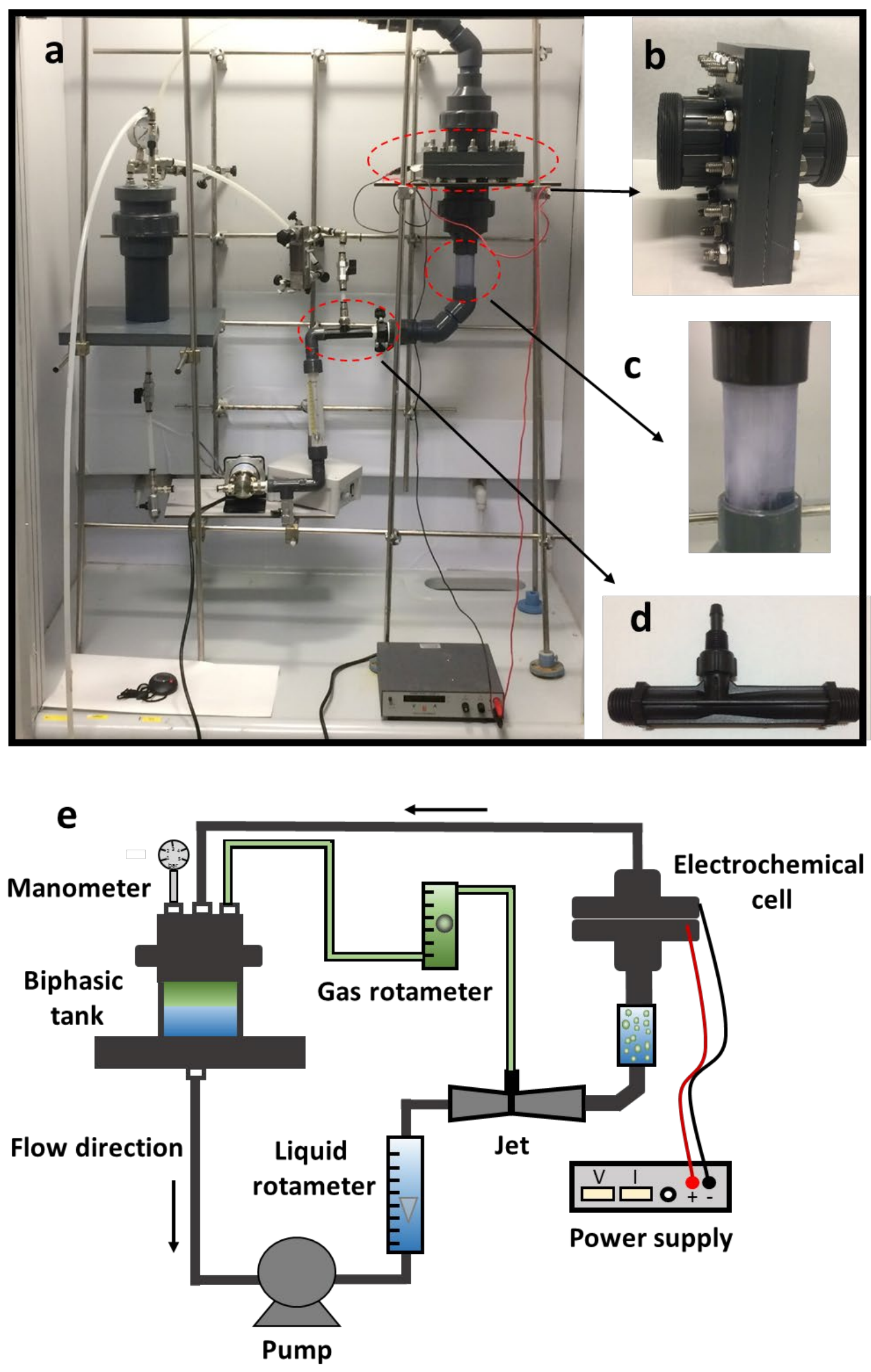
Figure 1. Experimental setup. a) Overview b) Microfluidic-flow through cell c)

Peephole d) Jet aerator e) Flow diagram (Pérez et al., 2018b).

As can be seen in Figure 1.e, the pump moves the fluid through the jet aerator (Figure 1.d) in whose throat the pressure drop act as the driving force to draw air into the pipeline, super-saturating in oxygen the electrolyte due to the formation of gas bubbles. The biphasic mixture is fed to the cell (Figure 1.b) and passes first through the anode and then the through the cathode, where in the latter the oxygen is reduced to $\mathrm{H}_{2} \mathrm{O}_{2}$.

\subsubsection{Electrochemical cell}

The cell design is a microfluidic flow-through as described in previous works (Pérez et al., 2017c; Pérez et al., 2018). In this case, the cell body was modified accordingly to withstand higher pressures and ensure the sealing to avoid gas/electrolyte leakage. It consists in two symmetric pieces held together by compression (Figure 1.b). Each piece holds one electrode which are separated by means of a solid PTFE plastic film (thickness $100 \mu \mathrm{m})$. Thin aluminum foils $(\approx 25 \mu \mathrm{m})$ are attached at both sides of the PTFE film and are in contact with the electrodes (but not with the electrolyte) acting as current feeders, creating an IE gap of about $150 \mu \mathrm{m}$.

\subsubsection{Electrode materials}

The anode was 8 x $9.5 \mathrm{~cm}$ titanium mesh coated with $\mathrm{RuO}_{2} / \mathrm{IrO}_{2}$ supplied by Magneto special anodes B.V. (The Netherlands). The cathodes were fabricated by depositing a mixture of $\mathrm{CB} / \mathrm{PTFE}$ on aluminum foam as support. $\mathrm{CB}$ was Vulcan XC72 fabricated by Cabot Corporation and distributed by Delta Tecnic, S.A. (Spain) and PTFE was a liquid emulsion in water (60\% wt.) supplied by Sigma-Aldrich (USA). Aluminum foams $\left(\right.$ Duocel $^{\circledR}$ ) of $8 \times 9.5 \mathrm{~cm}$ with 40 pores per inch (ppi), 6-8\% relative density and hickness ranging from 5 to $15 \mathrm{~mm}$ (Figure 2.a) were supplied by ERG Materials \& Aerospace 
(USA). The diameter of the inlet pipe of the electrochemical cell is $6.5 \mathrm{~cm}$ which corresponds to a frontal (wet) area of $33 \mathrm{~cm}^{2}$ for both electrodes.

The CB/PTFE mixture was deposited in the central part of the electrodes following a procedure similar to the one described previously (Pérez et al., 2017). The inks were prepared by dispersing $1 \mathrm{mg} \mathrm{mL}^{-1}$ of $\mathrm{CB}$ and $5 \mathrm{mg} \mathrm{mL}^{-1}$ of PTFE into isopropanol for 2 hours at $50^{\circ} \mathrm{C}$ in an ultrasound bath. After this, the aluminum foams were placed over a home-made plate at $130{ }^{\circ} \mathrm{C}$ and $200 \mathrm{~mL}$ of ink was sprayed (100 mL each side). For larger electrodes, the ink volume was multiplied according to the thickness (400 and $600 \mathrm{~mL}$ for electrodes with 10 and $15 \mathrm{~mm}$ thickness, respectively). After this, cathodes were annealed at $360{ }^{\circ} \mathrm{C}$ for $1 \mathrm{~h}$ starting from room temperature at a heating rate of $12{ }^{\circ} \mathrm{C} \mathrm{min}-$ ${ }^{1}$ (Figure 1.b).
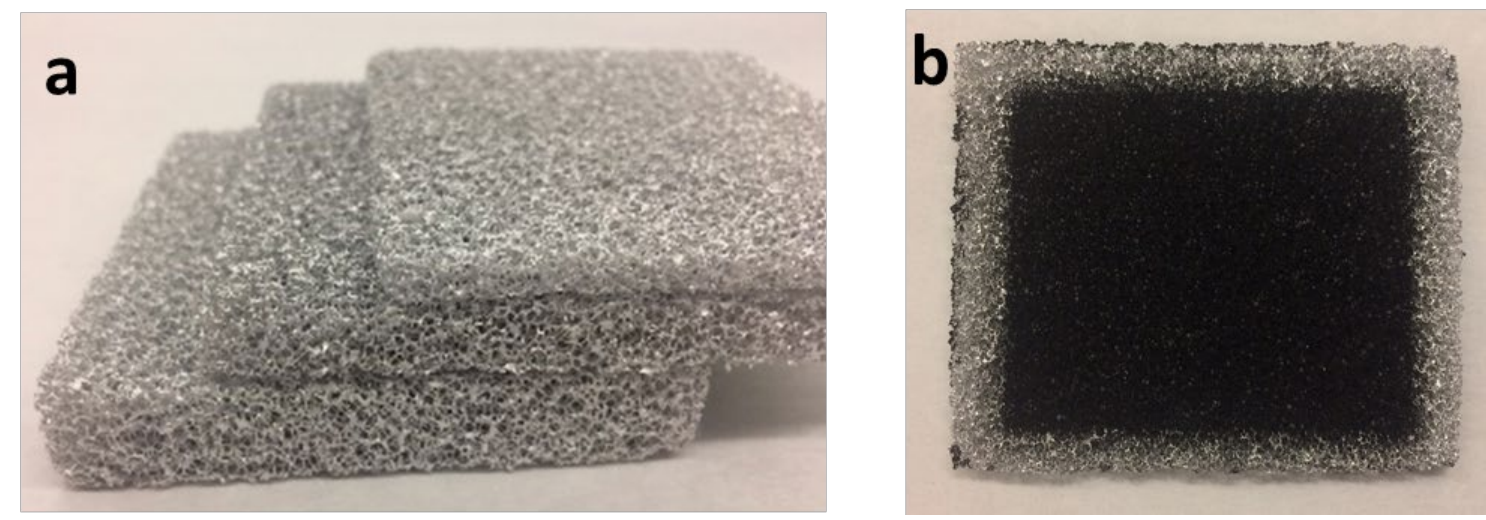

Figure 2. Aluminum foams $\left(\right.$ Duocel $\left.^{\circledR}\right)-40$ ppi $-6-8 \%$ relative density a) Raw foams with thickness from 5 to $15 \mathrm{~mm}$ b) Foam after the deposition of CB/PTFE

2.2 Analytical techniques

\subsubsection{Determination of $\mathrm{H}_{2} \mathrm{O}_{2}$}

$\mathrm{H}_{2} \mathrm{O}_{2}$ was measured by the potassium titanium (IV) oxalate method (Eisenberg, 1943) according to standard DIN 38 409, part 15, DEV-18.

2.2.2 Measurement of the ohmic resistance 
Ohmic resistance was calculated by using electrochemical impedance spectroscopy (EIS) carried out by means of a Potentiostat-Galvanostat Autolab 302N controlled with NOVA 2.1 software. EIS was applied using a sinusoidal perturbation with an amplitude of 0.01 $\mathrm{V}_{\mathrm{RMS}}$ - between $1 \cdot 10^{5}$ and $0.01 \mathrm{~Hz}$. The ohmic resistance is calculated from the intersection of the $\mathrm{X}$-axis in the Nyquist plot (-Z" vs $\left.\mathrm{Z}^{\prime}\right)$.

\subsection{Calculus}

\subsubsection{Current efficiency}

Current efficiency was calculated in galvanostatic according to Eq. 1 (Pérez et al., 2017a):

$$
\mathrm{CE}(\%)=\frac{\mathrm{n} \cdot \mathrm{F} \cdot \mathrm{C}_{\mathrm{H}_{2} \mathrm{O}_{2}} \cdot \mathrm{V}}{\mathrm{I} \cdot \mathrm{t}}
$$

Where $\mathrm{n}$ represents the stoichiometric number of electron transferred in the reduction of oxygen to $\mathrm{H}_{2} \mathrm{O}_{2}$ (2), F is the Faraday constant $\left(96487 \mathrm{C} \mathrm{mol}^{-1}\right), C_{\mathrm{H}_{2} \mathrm{O}_{2}}$ is the molar concentration of accumulated of $\mathrm{H}_{2} \mathrm{O}_{2}(\mathrm{M})$ in the bulk, $\mathrm{V}$ is the volume of the solution $\left(\mathrm{dm}^{3}\right), \mathrm{I}$ is the current intensity (A) and $\mathrm{t}$ is the electrolysis time (s).

\subsubsection{Specific energy consumption}

Energy consumption was calculated according to Eq. 2:

$$
E C\left(\mathrm{kWh} \mathrm{kg} \mathrm{H}_{2} \mathrm{O}_{2}^{-1}\right)=\frac{\mathrm{I} \cdot \mathrm{E}_{\mathrm{cell}} \cdot \mathrm{t}}{\mathrm{C}_{\mathrm{H}_{2} \mathrm{O}_{2}} \cdot \mathrm{V} \cdot 0.034}
$$

Where I is the current intensity (A), $E_{\text {cell }}$ is the cell voltage (V), $t$ is the electrolysis time (h), $\mathrm{C}_{\mathrm{H}_{2} \mathrm{O}_{2}}$ is the molar concentration of accumulated of $\mathrm{H}_{2} \mathrm{O}_{2}(\mathrm{M})$ at time $\mathrm{t}, \mathrm{V}$ is the volume of the solution $\left(\mathrm{dm}^{3}\right.$ ) and 0.034 is a conversion factor (molecular mass of $\mathrm{H}_{2} \mathrm{O}_{2}$ divided by 1000).

\section{Design basis}

The objective of this reactor is the cost-effective electro-chemical production of $\mathrm{H}_{2} \mathrm{O}_{2}$ by i) minimizing the ohmic drop, ii) maximizing mass transport and iii) optimizing the aeration system.

3.1 Minimization of ohmic drops 
The ohmic resistance is a key parameter to evaluate the design of an electrochemical cell to be applied industrially. It represents a loss of energy that must be minimized for an economical operation (Pletcher et al., 2014; Pletcher and Walsh, 1990). Electrical conductivity (reciprocal of ohmic resistance) of metals is, in general, several orders of magnitude higher than carbonaceous electrodes (except for graphene). In particular, metal conductivities are in the order of $10^{8} \mathrm{mS} \mathrm{cm}^{-1}$ and carbon-graphite is around three orders of magnitude less conductive $\left(10^{5} \mathrm{mS} \mathrm{cm}^{-1}\right)$ (Pletcher and Walsh, 1990). Therefore, the use of metallic electrodes is preferable to reduce undesirable ohmic resistances.

On its part, the ionic conductivity also gives rise to ohmic drops in the system. It depends not only on the concentration and mobility of ions but also on the length that charge is to be transported. Therefore, attention is to be paid to the IE gap, especially in systems with low-conductive electrolytes (Goodridge and Scott, 1995; Pérez et al., 2018a). In this design, the use of a narrow IE gap, such as in microfluidic reactors is proposed (Aoki et al., 2013; Elvira et al., 2013; Sabatino et al., 2016). Interestingly, a low IE gap makes the system less sensible to changes in electrolyte conductivity, improving and flexibility in operation.

The main limitation of conventional flow-by microfluidic electrochemical cells is that the reduction of the IE gap implies a reduction of the channel and a concomitantly increase of the pressure drop, limiting the flow rates to the order of $\mathrm{mL} \mathrm{min}^{-1}$ (Green et al., 2015; Sabatino et al., 2016; Scialdone et al., 2014). This circumstance hinders the application of high current densities when gas-evolving electrodes are used due to the hold-up of bubbles on the electrodes and the clogging of the IE gap (Bouzek et al., 2010; Krrišt'ál et al., 2008). To solve this, it is interesting the adoption of the microfluidic flow-through (MF-FT) cell configuration as reported in previous works (Pérez et al., 2017c; Pérez et al., 2018;). 
The aforementioned design requires the use of rigid and porous electrodes to avoid the contact between the electrodes and allow the liquid electrolyte to flow in and out of the IE gap. In this work, it is proposed the use of a metallic (aluminum) foam covered with an active phase of $\mathrm{CB} / \mathrm{PTFE}$ to produce $\mathrm{H}_{2} \mathrm{O}_{2}$ instead of the poorly-conductive RVC. In a previous work (Pérez et al., 2018), this change entailed a reduction of $40 \%$ ( 8.2 vs. 5 V) in cell voltage and, therefore, in energy consumption. In addition, a higher electrical conductivity implies a better current/voltage distribution which may facilitate the scale up (Pletcher and Walsh, 1990). Moreover, RVC is brittle and this is a problem in cells that are held together by compression (Walsh et al., 2016) while aluminum foam did not show any problem on this regard during this experience.

\subsection{Maximization of mass transport}

The MF-FT layout also maximizes the mass transport towards the electrode surfaces due to the use of $3 \mathrm{D}$ electrodes fed in flow-through. For example, the $\mathrm{k}_{\mathrm{m}}$ was $70 \%$ higher at an inlet flow of $0.78 \cdot 10^{-2} \mathrm{~m} \mathrm{~s}^{-1}$ in the flow-through in comparison to the flow-by and differences were increasingly marked at higher flow velocities (Pérez et al., 2018a). In addition, 3D electrode possess higher specific surface area allowing the design of electrochemical reactors with superior space-time yields (Arenas et al., 2017; Zhang et al., 2013). The aluminum foam used has a surface area of $18 \mathrm{~cm}^{2}$ per $\mathrm{cm}^{-3}$, according to the data of the manufacturer (ERG1).

Also, in a flow system, the pressure drop over the porous electrode is important since it directly affects the pump size and electrolyte circulation power requirements (Walsh et al., 2016). At the velocity used in this work $\left(1.34 \cdot 10^{-2} \mathrm{~m} \mathrm{~s}^{-1}\right)$ the pressure drop $(\Delta P / L)$, according to the data of the manufacturer (ERG2), could be considered negligible. In addition, the direction of the flow forces the electrolyte to move away from the porous 
electrode which, according to Zhou et al., would help to minimize the reduction of $\mathrm{H}_{2} \mathrm{O}_{2}$ to $\mathrm{H}_{2} \mathrm{O}$ inside the porous structure (Zhou et al., 2018).

\subsection{Optimization of the aeration system}

The aeration system is truly important to achieve high working current densities and CEs (Pérez et al., 2017a; Pérez et al., 2017b). The use of pressurized systems proved to be very efficient but the application of pressures $>10$ bar might compromise the economic viability of the process (Turton et al., 2008). Considering this fact, in this reactor it is proposed the use of a jet aerator and a pressurized circuit to supply high oxygen flow rates at moderated pressures due to the use of dissolved oxygen and pressurized air bubbles (Pérez et al., 2018b). Interestingly, the aeration capacity of the pressurized-jet at 6 bar and $160 \mathrm{dm}^{3} \mathrm{~h}^{-1}\left(21.9 \mathrm{~g} \mathrm{O}_{2} \mathrm{~h}^{-1}\right)$ is the same as a pressurized system at 17-18 bar.

The pressurized jet aerator is compatible with a MF-FT cell because it allows a high circulation of the fluid through via the narrow IE gap. In addition, the use of hermetic setups such the one presented here (working under pressure or not) can collect the oxygen evolved in the anode from water $/ \mathrm{H}_{2} \mathrm{O}_{2}$ oxidation. It is an important contribution that can provide up to $50 \%$ of the stoichiometric oxygen required in the cathode, making the most of a by-product and reducing energy consumption required for pressurization (Pérez et al., 2018b).

Therefore, this design joins together a system with low ohmic resistance (both in the electrolyte and the cathode), a high mass transfer due to the use of $3 \mathrm{D}$ electrodes fed in flow-through and a powerful aeration system.

\section{Experimental results}

4.1 Influence of current density in the production of $\mathrm{H}_{2} \mathrm{O}_{2}$

The current density governs the kinetics of electrochemical reaction/s and is often the key parameter to define the reactor size and investments cost of the installation. A series of 
experiments were performed at an intermediate pressure of 6 bar for current densities from 10 to $60 \mathrm{~mA} \mathrm{~cm}^{-3}$, defined with respect to the volume of the cathode.
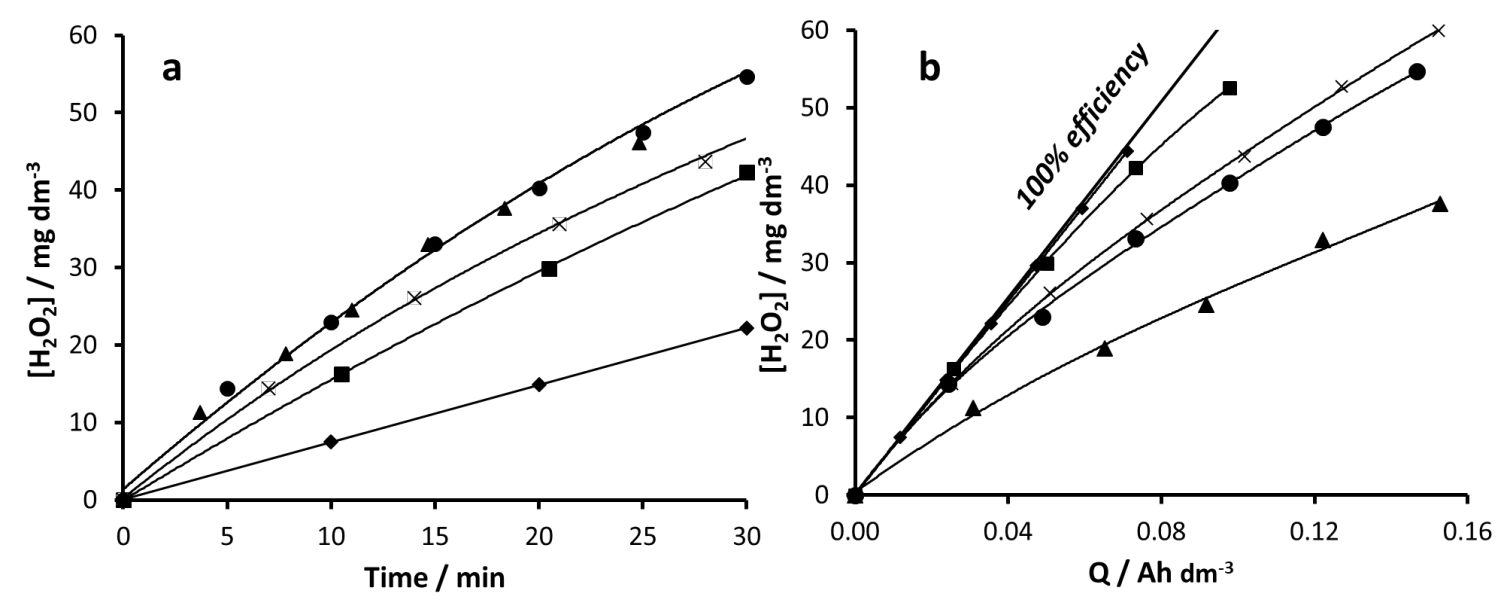

Figure 3. Evolution of $\mathrm{H}_{2} \mathrm{O}_{2}$ concentration at different current densities a) vs. time; b) vs. applied electric charge. P: 6 bar; Cathode volume $=16.5 \mathrm{~cm}^{3} ; Q_{\text {electrolyte }}=160 \mathrm{dm}^{3} \mathrm{~h}^{-1} ; \mathrm{T}$ $=25^{\circ} \mathrm{C} ; \mathrm{V}_{0}=2.25 \mathrm{dm}^{3}$; Electrolyte: $\mathrm{Na}_{2} \mathrm{SO}_{4} 0.05 \mathrm{M}$. IE gap $=150 \mu \mathrm{m} .100 \%$ efficiency line is calculated according to Faraday law (Eq. 1). $10 \mathrm{~mA} \mathrm{~cm}^{-3}=20 \mathrm{~mA} \mathrm{~cm}^{-3} \times 30$ $\mathrm{mA} \mathrm{cm}{ }^{-3} \bullet 40 \mathrm{~mA} \mathrm{~cm}{ }^{-3} \boldsymbol{\Delta} 60 \mathrm{~mA} \mathrm{~cm}^{-3}$.

According to Figure 3.a, instantaneous production rate (for a fixed Q of $0.03 \mathrm{Ah} \mathrm{dm}^{-3}$ ) increases with current density up to $40 \mathrm{~mA} \mathrm{~cm}^{-3}$, ranging from 6.3 at $10 \mathrm{~mA} \mathrm{~cm}{ }^{-3}$ to 24.5 $\mathrm{mg} \mathrm{H} \mathrm{H}_{2} \mathrm{O}_{2} \mathrm{~h}^{-1} \mathrm{~cm}^{-3}$ at $40 \mathrm{~mA} \mathrm{~cm}$. Further increase to $60 \mathrm{~mA} \mathrm{~cm} \mathrm{~cm}^{-3}$ does not lead to faster production. The production is not linear with time and $\mathrm{H}_{2} \mathrm{O}_{2}$ concentration does not increase with instantaneous production rate, due to the occurrence of parasitic reactions, mainly anodic oxidation (Eq. 3) and cathodic reduction to water (Eq. 4), as previously discussed in literature (Pérez et al., 2017d; Petrucci et al., 2016; Zhou et al., 2018).

$$
\begin{gathered}
\mathrm{H}_{2} \mathrm{O}_{2}-2 \mathrm{e}^{-} \rightarrow \mathrm{O}_{2}+2 \mathrm{H}^{+} \\
\mathrm{H}_{2} \mathrm{O}_{2}+2 \mathrm{e}^{-}+2 \mathrm{H}^{+} \rightarrow \mathrm{H}_{2} \mathrm{O}
\end{gathered}
$$

On its part, Figure 3.b compares the experimental concentration with the theoretical which assumes that all the charge is used in the production of $\mathrm{H}_{2} \mathrm{O}_{2}$. It generally follows 
a reverse trend with respect to current density. In the experiments discussed here, $\mathrm{H}_{2} \mathrm{O}_{2}$ is produced instantaneously (low Q values) with a selectivity of approximately $100 \%$ up to $20 \mathrm{~mA} \mathrm{~cm}^{-3}$ but decreases for higher current densities. At $60 \mathrm{~mA} \mathrm{~cm}$, the current efficiency was smaller ( $\cong 65 \%)$. It has been confirmed in previous studies that production rate and current efficiency increases under stronger aeration conditions (Pérez et al., 2017a; Pérez et al., 2017b, 2018b). Therefore, it seems reasonable to discuss the electrogeneration of $\mathrm{H}_{2} \mathrm{O}_{2}$ in terms of limiting current density, according to which above a certain value the oxygen transport to the surface is not sufficient to sustain the production of $\mathrm{H}_{2} \mathrm{O}_{2}$. Above this value, the excess of charge would be used in parasitic reactions such as $\mathrm{H}_{2}$ evolution or, even worse, $\mathrm{H}_{2} \mathrm{O}_{2}$ reduction to water (Eq. 4). The occurrence of the reaction show in Eq. 4 is of utmost importance because it destroys the existing product of interest. In this manner, working above the value of the current limiting density implies equal, or even smaller, production rates at higher energy consumptions.

\subsection{Influence of electrolyte conductivity on ohmic resistance}

On laboratory scale electrolyzers for $\mathrm{H}_{2} \mathrm{O}_{2}$ generation, the ohmic resistance is minimized by increasing electrolyte conductivity upon the addition of large concentration of salts, normally within the range $0.035-0.1 \mathrm{M} \mathrm{Na}_{2} \mathrm{SO}_{4}$ (Lu et al., 2017; Scialdone et al., 2015; $\mathrm{Yu}$ et al., 2015). It avoids extreme $\mathrm{E}_{\text {cell }}$ and temperature rise as a consequence of high ohmic drops in electrolytic systems (Martinez-Huitle et al., 2015). In Figure 4, the ohmic resistance and power consumption for electrolyte concentrations ranging from $0.0035 \mathrm{M}$ to $1 \mathrm{M}$ of $\mathrm{Na}_{2} \mathrm{SO}_{4}$ of the MF-FT is calculated. 

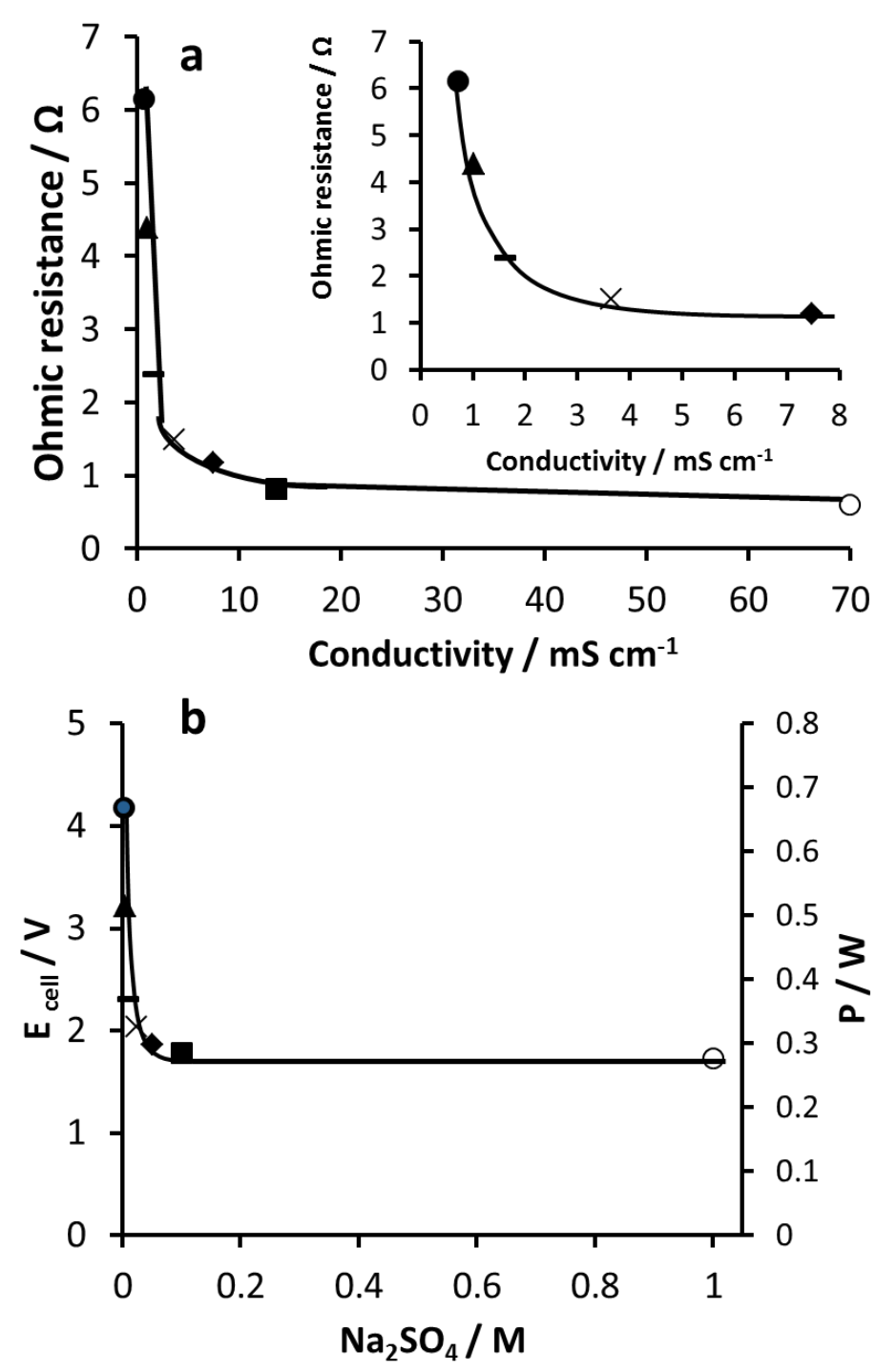

Figure 4. Evaluation of the ohmic resistance and the power consumption in the MF-FT for different electrolyte concentrations. a) ohmic resistance b) Cell voltage and electrical power consumption $(\mathrm{P})$ for $10 \mathrm{~mA} \mathrm{~cm}{ }^{-3} . \bullet 0.0035 \mathrm{M}$; $\Delta 0.005 \mathrm{M} ;-0.01 \mathrm{M} ; \mathbf{x} 0.025 \mathrm{M}$; • $0.05 \mathrm{M} ; \mathbf{\square} 0.1 \mathrm{M} ; \circ 1 \mathrm{M}$. Qelectrolyte $=160 \mathrm{dm}^{3} \mathrm{~h}^{-1} ; \mathrm{T}=25^{\circ} \mathrm{C}$; IE gap $=150 \mu \mathrm{m}$.

Ohmic resistance can be evaluated at the intersection of the plot with the $\mathrm{X}$-axis in the Nyquist plot (see Figure S.1 of supplementary material). As shown in Figure 4.a, ohmic resistance decreases with the addition of higher concentration salts. It varies one order of magnitude (from 6 to $0.6 \Omega$ ) when the electrolyte concentration increases 3 order of magnitude (from 0.0035 to $1 \mathrm{M}$ ) which clearly indicates that electrolyte concentration is progressively less effective in reducing ohmic resistance. In fact, it can be seen in Figure 
4.a that the variation of ohmic resistance with electrolyte conductivity is exponential. At low conductivities, small increases of electrolyte concentration lead to a considerable decrease in ohmic resistance. However, the increase of electrolyte of one order of magnitude (from 0.1 to $1 \mathrm{M}$ ) only leads to a reduction of $27 \%(0.83$ and $0.6 \Omega$, respectively). The last value should be close to the ohmic resistance of the system excluding the contribution of the electrolyte, a condition that is strictly achieved at infinite concentration. Thus, it can be deducted that the ohmic resistance in the electrolyte is the main contributor to the overall ohmic resistance and represents a bottleneck, which is in agreement with the electrical conductivity of the different component of the system, as discussed previously. The lower the ohmic resistance, the lower the cell voltage and also the electrical power, as shown in Figure 4.b, following the same decreasing tendency as ohmic resistance.

In comparison with previous systems, Lu et al. investigated the effect of electrode spacing on ohmic resistance in a stacked electrosynthesis reactor (SER) for the production of $\mathrm{H}_{2} \mathrm{O}_{2}$ (Lu et al., 2017). Ohmic resistances of 4.5, 1.3 and $1.1 \Omega$ were measured for IE gaps of 5, 2 and $1 \mathrm{~mm}$, respectively, using an $\mathrm{MMO}$ as counter electrode and $0.1 \mathrm{M} \mathrm{Na}_{2} \mathrm{SO}_{4}$ as supporting electrolyte. Using the same electrolyte concentration, the ohmic resistance in the present MF-FT is $0.8 \Omega$, approximately $30 \%$ less.

\subsection{Comparison with the state-of-the-art}

To put the pressurized-jet aerated MF-FT into context, its performance is compared with state-of-the-art reactors described in bibliography. For comparative purposes, the most relevant parameters for the future application of this reactor (ElectroFenton) are summarized in Table 1. 
Table 1. Comparison of jet-aerated MF-FT reactor with bibliography. $\left.{ }^{*}\right)$ Current density in $\mathrm{mA} \mathrm{cm}^{-3}$; $\left.{ }^{* *}\right)$ Current density referred to the current collector

\begin{tabular}{|c|c|c|c|c|c|c|c|}
\hline References & Cathode & IE gap / mm & Aeration & Electrolyte & $\begin{array}{l}\text { Current density / } \\
\qquad \mathbf{m A ~ c m} \text { cm }^{-2}\end{array}$ & $\begin{array}{l}\text { Production rate / } \\
\mathrm{mg} \mathrm{H}_{2} \mathrm{O}_{2} \mathbf{h}^{-1} \mathrm{~cm}^{-2}\end{array}$ & 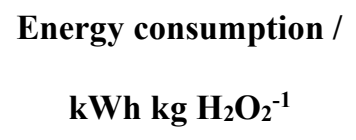 \\
\hline \multirow{2}{*}{ Present work } & \multirow{2}{*}{$\begin{array}{l}\text { CB/PTFE-Al } \\
\left(16.5 \mathrm{~cm}^{3}\right)\end{array}$} & \multirow{2}{*}{0.15} & \multirow{2}{*}{$\begin{array}{c}\text { Pressurized-jet (6 } \\
\text { bar) }\end{array}$} & $\mathrm{Na}_{2} \mathrm{SO}_{4} 0.05 \mathrm{M}$ & \multirow{2}{*}{$10^{*}$} & \multirow{2}{*}{6.3} & 3.6 \\
\hline & & & & $\mathrm{Na}_{2} \mathrm{SO}_{4} 0.0035 \mathrm{M}$ & & & 6.6 \\
\hline $\begin{array}{c}\text { (Pérez et al., } \\
\text { 2017a) }\end{array}$ & $\begin{array}{c}\text { CB/PTFE-CF } \\
\left(5 \mathrm{~cm}^{2}\right)\end{array}$ & 25 & $\begin{array}{c}\text { Pressurized air (31 } \\
\text { bar) }\end{array}$ & $\mathrm{Na}_{2} \mathrm{SO}_{4} 0.05 \mathrm{M}$ & 100 & 62.5 & 25.4 \\
\hline $\begin{array}{c}\text { (Pérez et al., } \\
\text { 2018) }\end{array}$ & $\begin{array}{c}\text { CB/PTFE-RVC } \\
(16.5 \mathrm{~cm} 3)\end{array}$ & 0.4 & Jet aerator (1 bar) & $\mathrm{Na}_{2} \mathrm{SO}_{4} 0.05 \mathrm{M}$ & $20 *$ & 12.4 & 7.8 \\
\hline $\begin{array}{l}\text { (Barros et } \\
\text { al., 2015) }\end{array}$ & $\begin{array}{c}\text { CB/PTFE-GDE } \\
\left(20 \mathrm{~cm}^{2}\right)\end{array}$ & n.a. & Oxygen & $1 \mathrm{M} \mathrm{KOH}$ & 212.5 & 25.7 & 8.0 \\
\hline $\begin{array}{l}\text { (Gupta and } \\
\text { Oloman, } \\
2006 \text { ) }\end{array}$ & $\begin{array}{c}\mathrm{CF}(63 \times 4 \times 0.3 \\
\left.\mathrm{cm}^{3}\right)\end{array}$ & $\begin{array}{c}0.039 \text { (diaphragm } \\
\text { tickness) }\end{array}$ & $\begin{array}{l}\text { Pressurized air ( } 9 \\
\text { bar) }\end{array}$ & $2 \mathrm{M} \mathrm{NaOH}$ & $100-500 * *$ & n.a. & $3.1-6.4$ \\
\hline $\begin{array}{c}\text { (Lu et al., } \\
\text { 2017) }\end{array}$ & $\begin{array}{c}\text { CB/PTFE-GDE } \\
\left(6 \times 7 \mathrm{~cm}^{2}\right)\end{array}$ & 1 & $\begin{array}{c}\text { Air }\left(0.150 \mathrm{~mL} \mathrm{~min}^{-}\right. \\
\left.{ }^{1}\right)\end{array}$ & $\mathrm{Na}_{2} \mathrm{SO}_{4} 0.1 \mathrm{M}$ & $10-50$ & $4.8-23.1$ & $4.6-9.8$ \\
\hline
\end{tabular}


To the best of the knowledge of the authors, the fastest production so far was reported in a previous work using $\mathrm{CB} / \mathrm{PTFE}$ carbon felt electrodes in a reactor under pressure (Pérez et al., 2017a), as shown in Table 1. Working under 31 bar of air pressure, an instantaneous specific production of $62.5 \mathrm{mg} \mathrm{H}_{2} \mathrm{O}_{2} \mathrm{~h}^{-1} \mathrm{~cm}^{-2}$ was measured. Despite this fact and the high $\mathrm{CE}(\cong 100 \%)$, the energy consumption is somewhat high $\left(25.4 \mathrm{kWh} \mathrm{kg} \mathrm{H}_{2} \mathrm{O}_{2}{ }^{-1}\right)$, probably because the use of a small anode, a carbon felt as support for the CB/PTFE mixture and, especially, a wide IE gap (25 mm). A considerable smaller production rate (12.4 $\mathrm{mg} \mathrm{H}_{2} \mathrm{O}_{2}$ $\mathrm{h}^{-1} \mathrm{~cm}^{-2}$ ) but with a much better specific energy consumption $\left(7.8 \mathrm{kWh} \mathrm{kg} \mathrm{H}_{2} \mathrm{O}_{2}{ }^{-1}\right)$ was measured in a jet-aerated MF-FT reactor using a CB/PTFE-RVC with 45 ppi. Interestingly, the cell voltage dropped by a $40 \%$ under the same conditions when the RVC as support was substituted by an aluminum foam, due to the higher conductivity of metal (around 3 orders of magnitude superior). However, no data regarding $\mathrm{H}_{2} \mathrm{O}_{2}$ production alone was reported in that work.

A similar value of energy consumption $\left(8 \mathrm{kWh} \mathrm{kg} \mathrm{H}_{2} \mathrm{O}_{2}{ }^{-1}\right.$ ) was reported by Barros et al. (Barros et al., 2015) for the production of alkaline $\mathrm{H}_{2} \mathrm{O}_{2}$ solutions which are employed as bleaching agent in the Kraft process. The production in strong alkaline medium has two important economic advantages. First, the high conductivity of the solution minimizes ohmic drop and, in addition, the thermodynamic potential for the reduction of $\mathrm{O}_{2}$ to $\mathrm{H}_{2} \mathrm{O}_{2}$ in alkaline medium is lower than in neutral-acid (-0.065 and $0.685 \mathrm{~V}$ both vs. SHE). Even smaller values $\left(3.1-6.4 \mathrm{kWh} \mathrm{kg} \mathrm{H}_{2} \mathrm{O}_{2}{ }^{-1}\right)$ were reported by Gupta et al. (Gupta and Oloman, 2006) in a pressurized system (9 bar) using CF cathodes in $2 \mathrm{M} \mathrm{NaOH}$ at high current densities of $100-500 \mathrm{~mA} \mathrm{~cm}^{-2}$ (referred to the current collector**).

In acid medium, the lowest energy consumptions have been recently reported by Lu et al. (Lu et al., 2017). In this work, the effect of several parameters, including the IE gap and the influence of electrode pairs, was studied and for the best configuration (6 electrode 
pairs, $0.21 \mathrm{~min}$ hydraulic retention time and $1 \mathrm{~mm}$ IE gap), specific energy consumptions within 4.6 to $9.8 \mathrm{kWh} \mathrm{kg} \mathrm{H}_{2} \mathrm{O}_{2}{ }^{-1}$ were reported at $10-50 \mathrm{~mA} \mathrm{~cm}{ }^{-2}$, but still using a salty electrolyte $(0.1 \mathrm{M})$. In the present work, the lowest energy consumption in acid medium so far is reported $\left(3.65 \mathrm{kWh} \mathrm{kg} \mathrm{H}_{2} \mathrm{O}_{2}{ }^{-1}\right)$, even if half the concentration of electrolyte $(0.05$ M) in comparison to Lu's work is used. The reactor presented in this work seems to be less sensible to electrolyte conductivity, due to the low IE gap, given that a reduction of 15 times in $\mathrm{Na}_{2} \mathrm{SO}_{4}$ concentration (from 0.05 to $0.0035 \mathrm{M}$ ) only results in an increase of

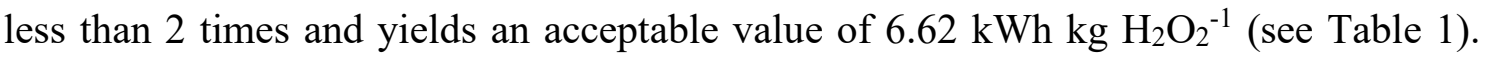
This result is of particular attractiveness for ElectroFenton and related technologies for wastewater treatment due to the fact that a $0.0035 \mathrm{M} \mathrm{Na}_{2} \mathrm{SO}_{4}$ has a conductivity of approximately $0.7 \mathrm{mS} \mathrm{cm}^{-1}$, typical of a wastewater with low ionic concentration.

\subsection{Preliminary scale-up}

Given the promising results obtained so far, a preliminary attempt to the scale-up of the reactor was conducted. The objective is to increase the production rate for which the cell was modified accordingly to fit thicker cathodes from 5 to $15 \mathrm{~mm}\left(16.5\right.$ to $\left.49.5 \mathrm{~cm}^{3}\right)$. The results in terms of concentration vs. time and specific charge, ohmic resistance, cell voltage and energy consumption are shown in Figure 5.
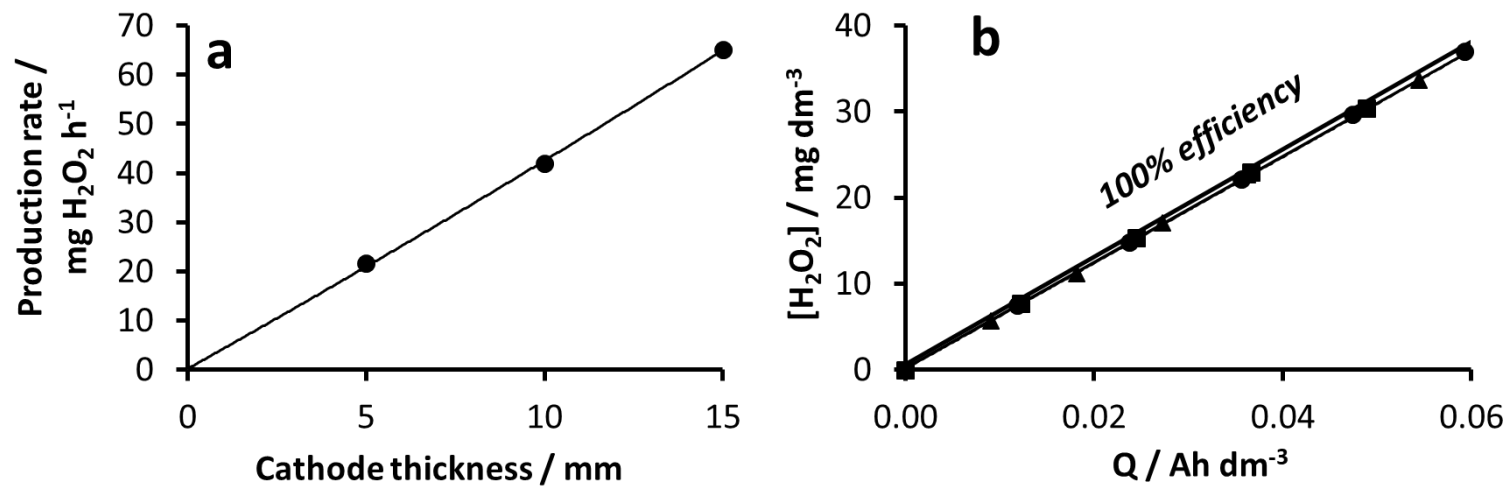
Figure 5. Results obtained in the preliminary scale-up of the MF-FT reactor. a) production rate vs. cathode thickness b) concentration vs. applied electric charge $\bullet 5 \mathrm{~mm}$ - $10 \mathrm{~mm} \Delta 15 \mathrm{~mm}$ P: 6 bar; Qelectrolyte $=160 \mathrm{dm}^{3} \mathrm{~h}^{-1} ; \mathrm{T}=25{ }^{\circ} \mathrm{C} ; \mathrm{V}_{0}=2.25 \mathrm{dm}^{3}$; Electrolyte: $\mathrm{Na}_{2} \mathrm{SO}_{4} 0.05 \mathrm{M}$; IE gap $=150 \mu \mathrm{m}$ Specifically, a cathodic current density of $10 \mathrm{~mA} \mathrm{~cm}^{-3}$ was selected because it is a value at which the process is not mass-transfer controlled as discussed previously in Figure 3. According to Figure 5.a, the increase in electrode thickness gave rise to a proportional increase in production rate when the electrode was $\mathrm{x} 2$ and $\mathrm{x} 3$ times thicker, obtaining 21.6, 41.9 and $65.2 \mathrm{mg} \mathrm{H}_{2} \mathrm{O}_{2} \mathrm{~h}^{-1}$ for electrodes of 5, 10 and $15 \mathrm{~mm}$, respectively. As shown in Figure 5.b, the current efficiency is kept constant in the scale-up (close to $100 \%$ in all the tests). In this manner, the increase in net intensity (from 0.165 to $0.495 \mathrm{~A}$ ) gives rise to a proportional generation of $\mathrm{H}_{2} \mathrm{O}_{2}$, which indicate that the system is readily scalable.

Theoretically, cathode thickness could be increased maintaining a high CE up to the point at which $i$ ) oxygen transfer to the cathodic surface is sufficient to maintain the production at the working current density ii) uniform voltage/current distribution is achieved along the electrode surface, otherwise CE may decrease. According to a previous work (Pérez et al., 2018b), the jet-pressurized aerator can supply an oxygen flow of $21.9 \mathrm{~g} \mathrm{O}_{2} \mathrm{~h}^{-1}$ at 6 bar and $160 \mathrm{dm}^{3} \mathrm{~h}^{-1}$ recirculation flow. It is the stoichiometric amount required to sustain the production of a cathode of $3,600 \mathrm{~cm}^{3}$ at $10 \mathrm{~mA} \mathrm{~cm}^{-3}$. In other words, a cathode with an equivalent length of $1 \mathrm{~m}, 70$ times larger than the thickest cathode used in this study. However, precaution has to be taken with current distribution which may be a critical parameter in the scale-up (Heitz and Kreysa, 1986; Martinez-Huitle et al., 2015; Pletcher and Walsh, 1990). A modelling step would be interesting for predicting current, electrolyte and gas distribution as previously conducted for other electrochemical systems 
at a higher degree of development such as fuel cells or water electrolyzers (Jomard et al., 2008; Úbeda et al., 2014; Vasile et al., 2017).

With respect to ohmic resistance, it slightly increases from 1.2 to $1.7 \Omega$ (see Figure 6.a) when cathode thickness augmented from 5 to $15 \mathrm{~mm}$. It is mainly attributed to the increase in electrode thickness because the larger the three-dimensional electrode, the bigger the average distance between the cathode and the counter electrode. There are different alternatives, such as an alternating anodes and cathodes layout, expanding the electrode in horizontal (instead of vertical, i.e. thickness), the use of electrodes with higher specific surface area (for example an aluminum foam with $100 \mathrm{ppi}$ ) or a combination thereof to scale up this system keeping the ohmic resistance low. 

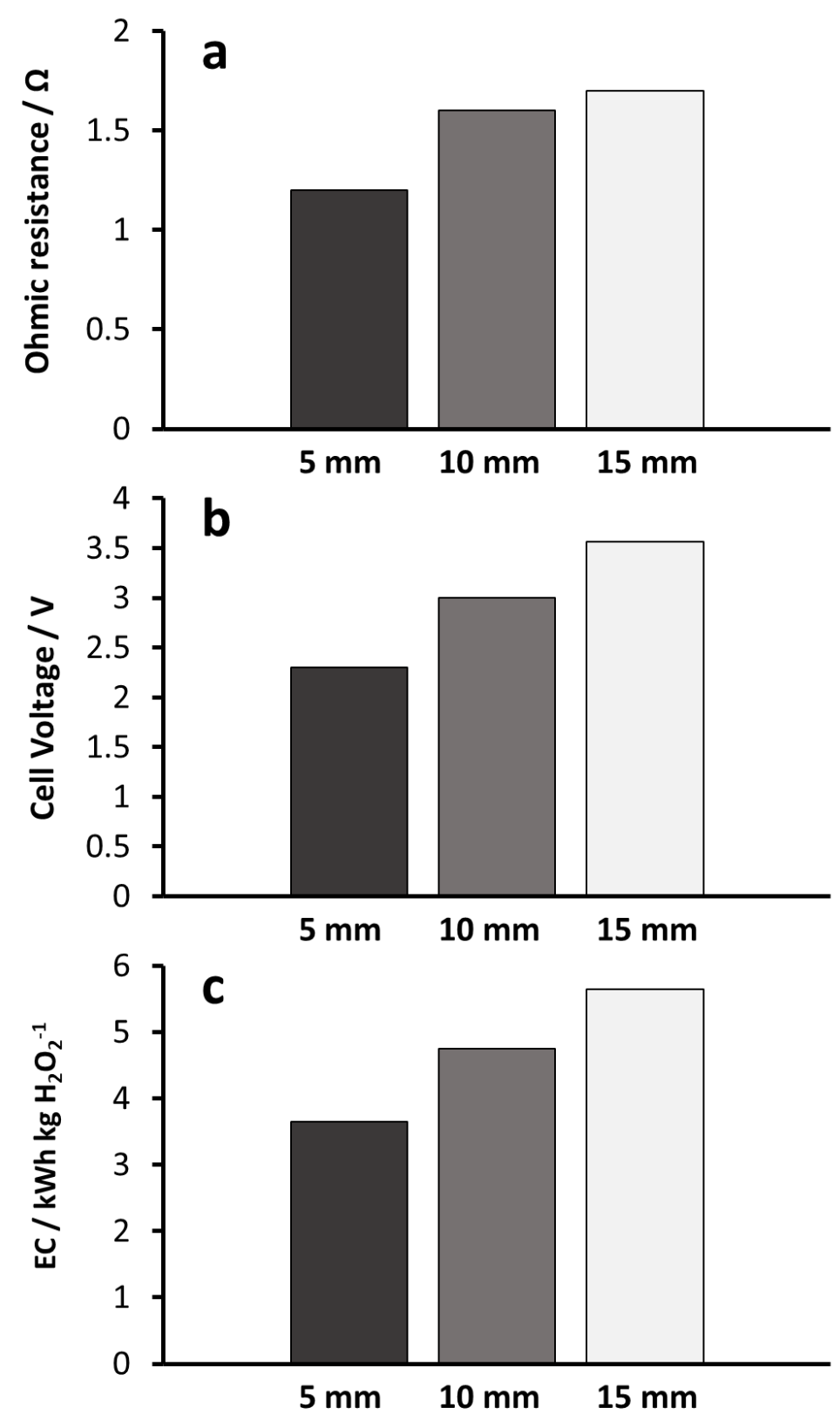

Figure 6. Ohmic resistance (a), cell voltage (b) and specific energy consumption for different cathode thicknesses

Concomitantly, cell voltage also increases with electrode thickness (Figure 6.b) from 2.3 $\mathrm{V}$ for the cathode of $5 \mathrm{~mm}$ thickness to more than $3.5 \mathrm{~V}$ in the case of the system equipped with the $15 \mathrm{~mm}$ cathode. The reason behind this is not only the increase in ohmic resistance and net current intensity but also is thought to be the higher current density (and the concomitantly larger over-potential) with respect to the anode, whose size is constant in this work. For an adequate scale-up, also the anode needs to be augmented in 
size to keep the anodic overpotential under control. The development of threedimensional electrodes with higher specific surface areas would be helpful on this regard. Interesting advances on this field have been recently reported such as metal-printing for electrode fabrication (Arenas et al., 2017) or deposition of high-surface porous electrocatalysts (Comisso et al., 2017; Comisso et al., 2015)

The rise of the cell voltage is reflected in an increase of the specific energy consumption from 3.65 to $5.65 \mathrm{kWh} \mathrm{kg} \mathrm{H}_{2} \mathrm{O}_{2}{ }^{-1}$ (Figure 6.c). Considering a value of $0.0816 € \mathrm{kWh}^{-1}$ (average prize in Europe in 2016 for medium-size industries (Eurostat)), it would entail a cost of $0.30-0.47 € \mathrm{~kg} \mathrm{H}_{2} \mathrm{O}_{2}{ }^{-1}$. Although the present estimation only includes the energy consumption of the cell, the value obtained is comparable to the current value of this commodity in the market (around $1 € \mathrm{~kg} \mathrm{H}_{2} \mathrm{O}_{2}{ }^{-1}$ (Ciriminna et al., 2016) which indicates that, after the adequate development of the process, electrochemical production may become a commercial alternative for decentralized $\mathrm{H}_{2} \mathrm{O}_{2}$ production in future low-carbon economies.

\section{Conclusions}

From this work, the following conclusions can be drawn:

- The performance of the novel pressurized-jet microfluidic flow-through reactor has been positively tested for the production of aqueous solutions of hydrogen peroxide.

- $\mathrm{H}_{2} \mathrm{O}_{2}$ is produced with an instantaneous current efficiency of $\cong 100 \%$ to a current density of $20 \mathrm{~mA} \mathrm{~cm}^{-3}$. Increasing current density up to $60 \mathrm{~mA} \mathrm{~cm}{ }^{-3}$ results counter-productive because it leads to the same production rate that at $40 \mathrm{~mA} \mathrm{~cm}^{-}$

${ }^{3}$ (25.4 $\mathrm{mg} \mathrm{H}_{2} \mathrm{O}_{2} \mathrm{~cm}^{3} \mathrm{~h}^{-1}$ ) but with lower current efficiency (65 vs. $90 \%$, respectively) and higher energy consumption (10.2 vs. $6.4 \mathrm{kWh} \mathrm{kg} \mathrm{H}_{2} \mathrm{O}_{2}$, 
respectively), highlighting the importance of the adequate selection of this parameter.

- Low ohmic resistances are obtained even if a low-conductive electrolyte is used, as for example $6 \Omega$ in a medium of $0.7 \mathrm{mS} \mathrm{cm}^{-1}$ ). Ohmic resistance decreases exponentially with electrolyte conductivity up to $0.01 \mathrm{M} \mathrm{Na}_{2} \mathrm{SO}_{4}$. Higher values do not lead to significant reductions ( $0.6 \Omega$ in $1 \mathrm{M} \mathrm{Na}_{2} \mathrm{SO}_{4}$ medium).

- Comparison with bibliography reveals that the pressurized-jet MF-FT yields the lowest energy consumption reported so far in neutral-acid medium $(3.65 \mathrm{kWh} \mathrm{kg}$ $\mathrm{H}_{2} \mathrm{O}_{2}{ }^{-1}$ at $10 \mathrm{~mA} \mathrm{~cm}{ }^{-3}$ in $0.05 \mathrm{M} \mathrm{Na}_{2} \mathrm{SO}_{4}$ medium). Energy consumption is still reasonable even at low electrolyte conductivity $\left(6.62 \mathrm{kWh} \mathrm{kg} \mathrm{H}_{2} \mathrm{O}_{2}{ }^{-1}\right.$ in $0.0025 \mathrm{M}$ $\mathrm{Na}_{2} \mathrm{SO}_{4}$ ), implying that this reactor could be successfully used for wastewater treatment as in Electro-Fenton and related technologies.

- A preliminary scale-up by increasing the cathode from 16.5 to $49.5 \mathrm{~cm}^{3}$ (5 to 15 mm thickness) demonstrated that they system is scalable and, therefore, is of potential industrial interest. Theoretical calculus suggests that, under the conditions employed in this work (6 bar and $160 \mathrm{dm}^{3} \mathrm{~h}^{-1}$ recirculation flow), the aeration system can supply the stoichiometric oxygen necessary to increase the cathode more than 70 times ( $\cong 1 \mathrm{~m}$ thickness).

\section{Acknowledgements}

Authors wish to express their gratitude to the financial support from the Spanish Ministry of Economy, Industry and Competitiveness and European Union through project CTM2016-76197-R (AEI/FEDER, UE) and to the University of Castilla-La Mancha for the pre-doctoral contract of José Fernando Pérez within the framework of the Plan Propio I + D. The technical advice of Felix Serrano and Jose Antonio Gascon in the assembly of the system is also gratefully acknowledged. 


\section{References}

Aoki, K.J., Li, C., Nishiumi, T., Chen, J., 2013. Electrolysis of pure water in a thin layer cell. Journal of Electroanalytical Chemistry 695, 24-29.

Arenas, L.F., Ponce de León, C., Walsh, F.C., 2017. 3D-printed porous electrodes for advanced electrochemical flow reactors: $\mathrm{A} \mathrm{Ni} /$ stainless steel electrode and its mass transport characteristics. Electrochemistry Communications 77, 133-137.

Barros, W.R.P., Ereno, T., Tavares, A.C., Lanza, M.R.V., 2015. In situ electrochemical generation of hydrogen peroxide in alkaline aqueous solution by using an unmodified gas diffusion electrode. ChemElectroChem 2(5), 714-719.

Bouzek, K., Jiřičný, V., Kodým, R., Křišt’ál, J., Bystroň, T., 2010. Microstructured reactor for electroorganic synthesis. Electrochimica Acta 55, 8172-8181.

C\&A Carnes and alimentosElvira, K.S., i Solvas, X.C., Wootton, R.C.R., deMello, A.J., 2013. The past, present and potential for microfluidic reactor technology in chemical synthesis. Nature Chemistry 5(11), 905-915.

Campos-Martin, J.M., Blanco-Brieva, G., Fierro, J.L.G., 2006. Hydrogen Peroxide Synthesis: An Outlook beyond the Anthraquinone Process. Angewandte Chemie International Edition 45(42), 6962-6984.

Ciriminna, R., Albanese, L., Meneguzzo, F., Pagliaro, M., 2016. Hydrogen peroxide: a key chemical for today's sustainable development. ChemSusChem 9(24), 3374-3381.

Comisso, N., Armelao, L., Cattarin, S., Guerriero, P., Mattarozzi, L., Musiani, M., Rancan, M., Vázquez-Gómez, L., Verlato, E., 2017. Preparation of porous oxide layers by oxygen bubble templated anodic deposition followed by galvanic displacement. Electrochimica Acta 253, 11-20.

Comisso, N., Cattarin, S., Guerriero, P., Mattarozzi, L., Musiani, M., Verlato, E., 2015. Oxygen bubble-templated anodic deposition of porous $\mathrm{PbO}_{2}$. Electrochemistry Communications 60, 144-147.

Chen, Q., 2006. Toward cleaner production of hydrogen peroxide in China. Journal of Cleaner Production 14(8), 708-712.

Chmayssem, A., Taha, S., Hauchard, D., 2017. Scaled-up electrochemical reactor with a fixed bed three-dimensional cathode for electro-Fenton process: Application to the treatment of bisphenol A. Electrochimica Acta 225, 435-442.

De Francesco, M., Costamagna, P., 2004. On the design of electrochemical reactors for the treatment of polluted water. Journal of Cleaner Production 12(2), 159-163.

Eisenberg, G., 1943. Colorimetric Determination of Hydrogen Peroxide. Industrial \& Engineering Chemistry Analytical Edition 15(5), 327-328.

ERG, ergaerospace.com/technical-data/surface-area-of-duocel-foam/ (access date $15 / 11 / 2017)$.

ERG, ergaerospace.com/technical-data/duocel-foam-pressure-drop-charts/ (access date 15/11/2017).

Eurostat, ec.europa.eu/eurostat/web/products-datasets/-/ten00117 (access date 18/12/2017).

Foller, P.C., Bombard, R.T., 1995. Processes for the production of mixtures of caustic soda and hydrogen peroxide via the reduction of oxygen. Journal of Applied Electrochemistry 25(7), 613-627.

Goodridge, F., Scott, K., 1995. Electrochemical process engineering: a guide to the design of electrolytic plant. Springer US.

Green, R., Brown, R., Pletcher, D., 2015. Understanding the performance of a microfluidic electrolysis cell for routine organic electrosynthesis. Journal of Flow Chemistry 5(1), 31-36. 
Gullá, A.F., Krasovic, J.L., 2014. Gas-diffusion electrode - Patent number: US20140227634A1. Industrie De Nora S.P.A.

Gupta, N., Oloman, C.W., 2006. Scale-up of the perforated bipole trickle-bed electrochemical reactor for the generation of alkaline peroxide. Journal of Applied Electrochemistry 36 (10), 1133-1141.

Heitz, E., Kreysa, G., 1986. Principles of Electrochemical Engineering: Extended Version of a DECHEMA Experimental Course. VCH.

Jomard, F., Feraud, J.P., Caire, J.P., 2008. Numerical modeling for preliminary design of the hydrogen production electrolyzer in the Westinghouse hybrid cycle. International Journal of Hydrogen Energy 33 (4), 1142-1152.

Křišt'ál, J., Kodým, R., Bouzek, K., Jiřičný, V., 2008. Electrochemical microreactor and gas-evolving reactions. Electrochemistry Communications 10 (2), 204-207.

Lei, Y., Liu, H., Shen, Z., Wang, W., 2013. Development of a trickle bed reactor of electro-Fenton process for wastewater treatment. Journal of Hazardous materials 261, 570-576.

Li, Q., Batchelor-McAuley, C., Lawrence, N.S., Hartshorne, R.S., Jones, C.J.V., Compton, R.G., 2014. A flow system for hydrogen peroxide production at reticulated vitreous carbon via electroreduction of oxygen. Journal of Solid State Electrochemistry 18 (5), 1215-1221.

Lu, Y., Liu, G., Luo, H., Zhang, R., 2017. Efficient in-situ production of hydrogen peroxide using a novel stacked electrosynthesis reactor. Electrochimica Acta 248, 2936.

Martinez-Huitle, C.A., Rodrigo, M.A., Sires, I., Scialdone, O., 2015. Single and Coupled Electrochemical Processes and Reactors for the Abatement of Organic Water Pollutants: A Critical Review. Chemical Reviews 115 (24), 13362-13407.

Moraes, A., Assumpção, M.H.M.T., Simões, F.C., Antonin, V.S., Lanza, M.R.V., Hammer, P., Santos, M.C., 2016. Surface and catalytical effects on treated carbon materials for hydrogen peroxide electrogeneration. Electrocatalysis 7(1), 60-69. Murayama, T., Yamanaka, I., 2011. Electrosynthesis of neutral $\mathrm{H}_{2} \mathrm{O}_{2}$ solution from $\mathrm{O}_{2}$ and water at a mixed carbon cathode using an exposed solid-polymer-electrolyte electrolysis cell. Journal of Physical Chemistry C 115 (13), 5792-5799.

Oloman, C., Watkinson, A.P., 1975. The electroreduction of oxygen to hydrogen peroxide on fluidized cathodes. The Canadian Journal of Chemical Engineering 53 (3), 268-273.

Pérez, J.F., Galia, A., Rodrigo, M.A., Llanos, J., Sabatino, S., Sáez, C., Schiavo, B., Scialdone, O., 2017a. Effect of pressure on the electrochemical generation of hydrogen peroxide in undivided cells on carbon felt electrodes. Electrochimica Acta 248, 169177.

Pérez, J.F., Llanos, J., Sáez, C., López, C., Cañizares, P., Rodrigo, M.A., 2016. Electrochemical jet-cell for the in-situ generation of hydrogen peroxide.

Electrochemistry Communications 71, 65-68.

Pérez, J.F., Llanos, J., Sáez, C., López, C., Cañizares, P., Rodrigo, M.A., 2017b. The jet aerator as oxygen supplier for the electrochemical generation of $\mathrm{H}_{2} \mathrm{O}_{2}$. Electrochimica Acta 246, 466-474.

Pérez, J.F., Llanos, J., Sáez, C., López, C., Cañizares, P., Rodrigo, M.A., 2017c. A microfluidic flow-through electrochemical reactor for wastewater treatment: A proof-ofconcept. Electrochemistry Communications 82, 85-88.

Pérez, J.F., Llanos, J., Sáez, C., López, C., Cañizares, P., Rodrigo, M.A., 2018a.

Development of an innovative approach for low-impact wastewater treatment: a 
microfluidic flow-through electrochemical reactor. Chemical Engineering Journal 351, 766-772.

Pérez, J.F., Llanos, J., Sáez, C., López, C., Cañizares, P., Rodrigo, M.A., 201. On the design of a jet-aerated microfluidic flow-through reactor for wastewater treatment by electro-Fenton. Separation and Purification Technology 208, 123 - 129.

Pérez, J.F., Llanos, J., Sáez, C., López, C., Cañizares, P., Rodrigo, M.A., 2018b. The pressurized jet aerator: A new aeration system for high-performance $\mathrm{H}_{2} \mathrm{O}_{2}$ electrolyzers. Electrochemistry Communications 89, 19-22.

Pérez, J.F., Sáez, C., Llanos, J., Cañizares, P., López, C., Rodrigo, M.A., 2017d. Improving the Efficiency of Carbon Cloth for the Electrogeneration of $\mathrm{H}_{2} \mathrm{O}_{2}$ : Role of Polytetrafluoroethylene and Carbon Black Loading. Industrial and Engineering Chemistry Research 56 (44), 12588-12595.

Petrucci, E., Da Pozzo, A., Di Palma, L., 2016. On the ability to electrogenerate hydrogen peroxide and to regenerate ferrous ions of three selected carbon-based cathodes for electro-Fenton processes. Chemical Engineering Journal 283, 750-758. Pletcher, D., 1999. Indirect Oxidations Using Electrogenerated Hydrogen Peroxide. Acta Chemica Scandinavica 53, 745-750.

Pletcher, D., Tian, Z.Q., Williams, D.E., 2014. Developments in Electrochemistry: Science Inspired by Martin Fleischmann.

Pletcher, D., Walsh, F.C., 1990. Industrial Electrochemistry. Springer Netherlands. Sabatino, S., Galia, A., Scialdone, O., 2016. Electrochemical Abatement of Organic Pollutants in Continuous-Reaction Systems through the Assembly of Microfluidic Cells in Series. ChemElectroChem 3 (1), 83-90.

Scialdone, O., Corrado, E., Galia, A., Sirés, I., 2014. Electrochemical processes in macro and microfluidic cells for the abatement of chloroacetic acid from water.

Electrochimica Acta 132, 15-24.

Scialdone, O., Galia, A., Gattuso, C., Sabatino, S., Schiavo, B., 2015. Effect of air pressure on the electro-generation of $\mathrm{H}_{2} \mathrm{O}_{2}$ and the abatement of organic pollutants in water by electro-Fenton process. Electrochimica Acta 182, 775-780.

Scialdone, O., Galia, A., Sabatino, S., 2013. Electro-generation of $\mathrm{H}_{2} \mathrm{O}_{2}$ and abatement of organic pollutant in water by an electro-Fenton process in a microfluidic reactor. Electrochemistry Communications 26 (1), 45-47.

Tang, Q., Wang, D., Yao, D.M., Yang, C.W., Sun, Y.C., 2016. Highly efficient electrogeneration of hydrogen peroxide using NCNT/NF/CNT air diffusion electrode for electro-Fenton degradation of p-nitrophenol. Water Science and Technology 73 (7), 1652-1658.

Turton, R., Bailie, R.C., Whiting, W.B., Shaeiwitz, J.A., 2008. Analysis, Synthesis and Design of Chemical Processes. Pearson Education.

Úbeda, D., Cañizares, P., Rodrigo, M.A., Pinar, F.J., Lobato, J., 2014. Durability study of HTPEMFC through current distribution measurements and the application of a model. International Journal of Hydrogen Energy 39 (36), 21678-21687.

Vasile, N.S., Monteverde Videla, A.H.A., Specchia, S., 2017. Effects of the current density distribution on a single-cell DMFC by tuning the anode catalyst in layers of gradual loadings: Modelling and experimental approach. Chemical Engineering Journal 322, $722-741$.

Verdaguer-Casadevall, A., Deiana, D., Karamad, M., Siahrostami, S., Malacrida, P., Hansen, T.W., Rossmeis1, J., Chorkendorff, I., Stephens, I.E.L., 2014. Trends in the electrochemical synthesis of $\mathrm{H}_{2} \mathrm{O}_{2}$ : enhancing activity and selectivity by electrocatalytic site engineering. Nano Letters 14 (3), 1603-1608. 
Vogt, H., 2012. The actual current density of gas-evolving electrodes - Notes on the bubble coverage. Electrochimica Acta 78, 183-187.

Walsh, F.C., Arenas, L.F., Ponce de León, C., Reade, G.W., Whyte, I., Mellor, B.G., 2016. The continued development of reticulated vitreous carbon as a versatile electrode material: Structure, properties and applications. Electrochimica Acta 215, 566-591.

Yamanaka, I., Murayama, T., 2008. Neutral $\mathrm{H}_{2} \mathrm{O}_{2}$ synthesis by electrolysis of water and O2. Angewandte Chemie, International Edition in English 47(10), 1900-1902.

Yu, F., Zhou, M., Yu, X., 2015. Cost-effective electro-Fenton using modified graphite felt that dramatically enhanced on $\mathrm{H}_{2} \mathrm{O}_{2}$ electro-generation without external aeration.

Electrochimica Acta 163, 182-189.

Zhang, C., Jiang, Y., Li, Y., Hu, Z., Zhou, L., Zhou, M., 2013. Three-dimensional electrochemical process for wastewater treatment: A general review. Chemical Engineering Journal 228, 455-467.

Zhao, K., Su, Y., Quan, X., Liu, Y., Chen, S., Yu, H., 2018. Enhanced $\mathrm{H}_{2} \mathrm{O}_{2}$ production by selective electrochemical reduction of $\mathrm{O}_{2}$ on fluorine-doped hierarchically porous carbon. Journal of Catalysis 357, 118-126.

Zhou, W., Gao, J., Ding, Y., Zhao, H., Meng, X., Wang, Y., Kou, K., Xu, Y., Wu, S., Qin, Y., 2018. Drastic enhancement of $\mathrm{H}_{2} \mathrm{O}_{2}$ electro-generation by pulsed current for ibuprofen degradation: Strategy based on decoupling study on $\mathrm{H}_{2} \mathrm{O}_{2}$ decomposition pathways. Chemical Engineering Journal 338, 709-718.

\section{Supplementary material}

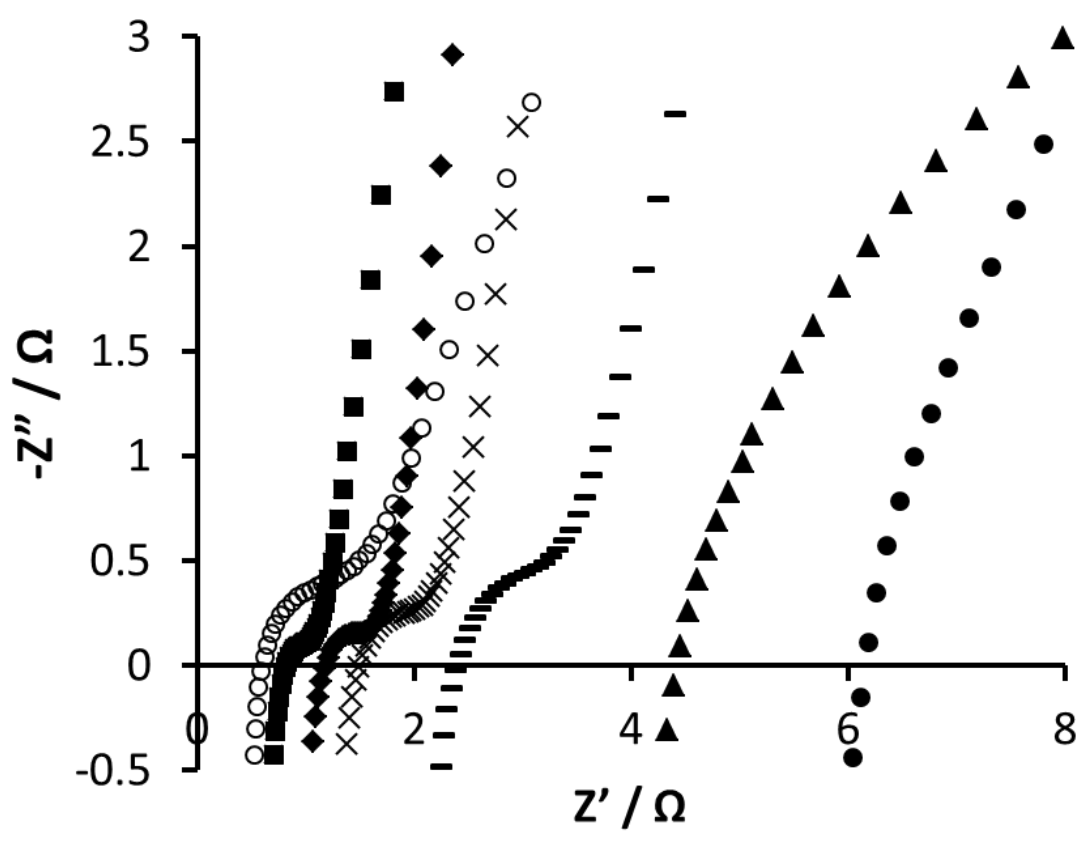


Figure S1. Nyquist plot for different electrolyte concentrations. $\bullet 0.0035 \mathrm{M} ; \boldsymbol{\Delta} 0.005$ $\mathrm{M} ;-0.01 \mathrm{M} ; \mathbf{x} 0.025 \mathrm{M} ; \diamond 0.05 \mathrm{M} ; \mathbf{\square} 0.1 \mathrm{M} ; \circ 1 \mathrm{M} . \mathrm{Q}_{\text {electrolyte }}=160 \mathrm{dm}^{3} \mathrm{~h}^{-1} ; \mathrm{T}=25^{\circ} \mathrm{C}$; IE gap $=150 \mu \mathrm{m}$. 